\title{
THREE NEW SPECIES OF PLEUROTHALLIS (ORCHIDACEAE: PLEUROTHALLIDINAE) IN SUBSECTION MACROPHYLLAE- FASCICULATAE FROM NORTHERN SOUTH AMERICA
}

\author{
Mark Wilson $^{1,10}$, Luis Baquero ${ }^{2}$, Katharine Dupree ${ }^{1}$, Marco M. Jiménez ${ }^{3}$, \\ Cheryl M. LeBlanc ${ }^{4}$, Gilberto Merino ${ }^{5}$, Jose Portilla 6 , Marcos Salas Guerrero ${ }^{7}$, \\ Francisco Tobar SuÁrez ${ }^{8} \&$ Jon D. Werner ${ }^{9}$ \\ ${ }^{1}$ Department of Organismal Biology and Ecology, Colorado College, Colorado Springs, CO 80903, U.S.A. \\ 2 Jardin Botanico de Quito, Pasaje \#34, Rumipampa E6-264 y Av Shyris, Interior Parque La Carolina, \\ Quito, Ecuador \\ ${ }^{3}$ Av. del Ejército y Juan Izquierdo, 190102, Zamora, Ecuador \\ ${ }^{4}$ Department of Biology, Ball State University, Muncie, IN 47306, U.S.A. \\ ${ }^{5}$ EquaflorA, Pedro Álvarez Cabral 1-69 Y Av. Don Bosco, Cuenca Ecuador \\ ${ }^{6}$ Ecuagenera, Km. 2 1/1 Vía a Cuenca Sector Llampasay, Gualaceo, Ecuador \\ ${ }^{7}$ Nature and Culture International, Chachapoyas, Peru \\ ${ }^{8}$ Arupos, E2 y Av. Yaloman, Quito, Ecuador \\ 98117 Northway SW, Lakewood, WA 98498, U.S.A. \\ ${ }^{10}$ Author for correspondence: mwilson@coloradocollege.edu
}

\begin{abstract}
The history of the taxonomy of Pleurothallis R.Br. subsection Macrophyllae-Fasciculatae and recent descriptions in that group are summarized. The phylogenetic position of the group based on preliminary molecular data and the appropriateness of the proposed genera Acronia C.Presl. and Zosterophyllanthos Szlach. \& Marg. for this group are discussed. Three new species from northern South America are described: Pleurothallis rubrifolia from southeastern Ecuador and northeastern Peru; Pleurothallis nangaritzae from southeastern Ecuador; and Pleurothallis castanea. Labellar micromorphology examined by scanning electron microscopy for P. rubrifolia and $P$. nangaritzae is discussed in relation to taxonomy and possible pollinator interactions.
\end{abstract}

Key words: Acronia, Macrophyllae-Fasciculatae, Pleurothallidinae, Pleurothallis, SEM, Zosterophyllanthos

Introduction. In his initial reorganization of the genus Pleurothallis R.Br., Luer (1986) retained section Macrophyllae-Fasciculatae of subgenus Pleurothallis, created by Lindley (1859). Subsequently, Macrophyllae-Fasciculatae was demoted to a subsection within section Pleurothallis, joining subsections Acroniae, Antenniferae, Longiracemosae and Macrophyllae-Racemosae (Luer 1988). However, a few years later Luer (2005) elevated subsections Acroniae and MacrophyllaeFasciculatae to generic level under the resurrected name Acronia C.Presl., creating under it sections Acronia, Amphigya and Macrophyllae-Fasciculatae. Luer (2005) recognized 213 species in Acronia section Macrophyllae-Fasciculatae at that time.

Inanalternate approach, Szlachetko and Margonska
(2001) created the genus Zosterophyllanthos Szlach. \& Marg. for Pleurothallis subsection MacrophyllaeFasciculatae, based in part upon the bilobed stigma, a characteristic trait of this group. A total of 189 species were transferred to that genus (Kolanowska, PérezEscobar, Sánchez \& Szlachetko 2011, Szlachetko \& Kulak 2006 a, b, Szlachetko \& Margonska 2001, Szlachetko, Veyret, Mytnik-Ejsmont, Sawicka, Rutkowski \& Baranow 2012). Apart from Pleurothallis allenii L.O.Williams, species of Pleurothallis subsection Acroniae were not moved to the new genus, this being the major distinction between the taxonomies of Luer (2005) and the Szlachetko group (Szlachetko \& Margonska 2001, Szlatcheko \& Kulak 2006 a, b).

The molecular phylogenetic study of the 
Pleurothallidinae by Pridgeon, Solano \& Chase (2001) included only three species from Pleurothallis subsection Macrophyllae-Fasciculatae, Pleurothallis cardiantha Rchb.f., Pleurothallis cardiothallis Rchb.f. and Pleurothallis teaguei Luer. In the phylogeny based on nrDNA ITS these species grouped closely with the type of genus Pleurothallis, Pleurothallis ruscifolia R.Br. Consequently, Pleurothallis subsection Macrophyllae-Fasciculatae was included in the circumscription of Pleurothallis (Pridgeon \& Chase 2001, Pridgeon, Cribb, Chase \& Rasmussen 2005). The ongoing phylogenetic studies of Pleurothallis by Wilson et al. $(2011,2013)$ and Wilson (unpubl. data), incorporating a much more extensive sampling of species from the subgenera included in this circumscription, support the inclusion of subsection Macrophyllae-Fasciculatae within Pleurothallis. In other words, the available evidence does not support the elevation of subsection MacrophyllaeFasciculatae to the level of genus, either along with subsection Acroniae under genus Acronia (Luer 2005) or alone as genus Zosterophyllanthos (Kolanowska et al. 2011, Szlachetko \& Kulak 2006 a, b, Szlachetko \& Margonska 2001, Szlachetko et al. 2012)

In the decade or so since the revision of Pleurothallis subsection Macrophyllae-Fasciculatae (Luer 2005) ten new species have been described in this group: four under Pleurothallis (Pleurothallis anthurioides A.Doucette; Pleurothallis adventurae Karremans \& Bogarín; Pleurothallis gigiportillae A.Doucette \& J.Portilla; and Pleurothallis oscarii Archila \& Chiron); five under Acronia (Acronia barbosae Luer \& Thoerle; Acronia miniatura Luer, Thoerle \& F.Werner; Acronia rinkei Luer; Acronia rhinocera Luer \& Sijm; and Acronia tobarii Luer \& Hirtz); and one under Zosterophyllanthos (Zosterophyllanthos dariensis Kolan. \& Szlach). All these species described under Acronia and Zosterophyllanthos have subsequently been transferred to Pleurothallis. Depending on synonymy, there are currently between 223 and 297 species attributable to Pleurothallis subsection Macrophyllae-Fasciculatae.

While labellar micro-morphology has been examined in some Pleurothallidinae, such as in Brazilian Octomeria species (Cardoso-Gustafson
2014) and Stelis species (Ignowski 2015, Ignowski, de Brito, Bona \& de Camargo Smidt 2015), labellar micro-morphology has not been examined to date in Pleurothallis subsection MacrophyllaeFasciculatae. Of particular interest in the labellar micro-morphology of some Pleurothallidinae is the so-called "glenion", described by Luer (1986) as a "well-demarcated, more or less circular structure, on the front surface of the lip just above the base and positioned beneath the stigma". Luer (1986) speculated that "in all likelihood it plays an important role in attracting the pollinator" and Duque (2008) that "perhaps the glenion facilitates the entry of the visitor to this area". While in Stelis some progress has been made in the understanding of the morphology and function of the glenion at the base of the hypochile (Ignowski et al. 2015), almost nothing is known about the glenion of Pleurothallis subsection Macrophyllae-Fasciculatae.

In this paper we describe three new species of Pleurothallis from subsection MacrophyllaeFasciculatae and present preliminary data on labellar micro-morphology and glenion structure.

\section{Materials and Methods}

Collections of plant material - Material collected in Ecuador (collections \#2020, \#2095 and \#2050) were made under investigation permit \#018-2016-ICFLO-FAU-DPAZCH-UPN-VS/MA granted to EcuaCorriente S.A. (ECSA). Specimens were moved under the transportation permit \#UPN-VSGM-025-2016 granted to and managed by Ecotono, Ecuador. Material from Peru was collected under a permit \#N 292-2016-SERFOR/DGGSPFFS granted to Marcos Salas Guerrero by the Servicio Nacional Forestal y de Fauna Silvestre (SERFOR), Peru. Plants were also imported into the U.S.A. through purchases from Ecuagenera (Gualaceo, Ecuador), EquaflorA (Cuenca, Ecuador) and Mundiflora (Cuenca, Ecuador) and grown in the collections of Wilson and Werner. Material from these latter plants was used for the creation of herbarium specimens accessioned into the herbarium at Colorado College (COCO). Flowers were preserved in Kew Mix $(5 \%$ formalin $[37.6 \%$ formaldehyde], $53 \%$ methanol, $5 \%$ glycerol, $37 \%$ deionized water). 
Morphology and taxonomic comparisons -. Living material of each collected species was examined by the first author in the collections of Ecuagenera, EquaflorA, and Mundiflora, as well as in the collection of imported plants at Colorado College. These materials were used for creation of the Lankester composite digital plates (LCDPs) and for morphological and taxonomic comparisons. Photographs were taken with a Canon EOS 40D using a Canon $100 \mathrm{~mm}$ f2.8 macro-lens and extension tubes as required. In order to determine novelty, these species were compared to a database of species descriptions, photographs and scans of types amassed by the first author over a 10-year period, as well as all pertinent literature, including but not limited to: Bennet and Christenson (1993); Dodson (2003); Dodson and Dodson (1980, 1982, 1991); Escobar (1994, 2006); Luer (1974, 1975a, b, 1976, 1977, 1986, 1988, 2005, 2009, 2011); Luer and Thoerle (2013); Schweinfurth (1959, 1970); and Zelenko and Bermudez (2009). Floras and other taxonomic materials from Colombia and Peru were included, because of the possibility that some of the species in the collections of Ecuagenera, EquaflorA and Mundiflora may be originally derived from those two countries and do not in fact occur naturally in Ecuador. Such appears to be the case with Pleurothallis neorinkei A.Doucette (from Colombia) Doucette et al. (2016) and Pleurothallis papillingua A.Doucette and J.Portilla (from Peru) (Wilson, unpubl. data). Species were compared in detail to those with which they may be confused, such as the Pleurothallis cardiostola Rchb.f. complex (Fig. 1-2), or have been confused, such as Pleurothallis canidentis Luer \& R.Escobar.

Scanning electron microscopy -. Fresh-harvested flowers were preserved in Kew Mix. For scanning electron microscopy (SEM) flowers were dehydrated in successively higher concentrations of ethanol $(80 \%, 95 \%, 100 \%, 100 \%)$ for $15 \mathrm{~min}$ each before being placed in freshly-opened $100 \%$ ethanol. Specimens were dehydrated in a critical point dryer (EMS 850) prior to mounting and sputter coating. Specimens were imaged using a Jeol JSM-6390LV scanning electron microscope with an accelerating voltage of $10-15 \mathrm{kV}$.

\section{Results}

The labellum or "lip" of Pleurothallis rubrifolia is quite unique, even when imaged with conventional macro-photography (Figs. 3c, 4b, 5b, 6). The "glenion", a small depression in the hypochile just in front of the anther, is oval in shape and is elevated significantly above the surrounding depression on a callus. In SEM (Fig. 7) the glenion appears to consist of three concentric layers of different cell types, surrounded by a depression with cells forming a smooth surface. The elevated areas of the lip consist of papillae which increase in packing density outward from the depression, creating another smooth surface. With conventional macrophotography the lip of Pleurothallis nangaritzae is observed to possess a bilobed glenion, a rare character in Pleurothallis subsection MacrophyllaeFasciculatae, and a few papillae along the outer edges. In SEM, it is apparent that papillae cover a significant portion of the lip surface and surround a triangular area of smooth tissue, with the glenion at the base (see images under the Discussion). The cellular structure of the glenion itself was not visible due to a covering of dehydrated liquid, presumably from the secretions of the glenion. The lip of Pleurothallis castanea was not imaged.

\section{Taxonomy}

Pleurothallis rubrifolia Mk.Wilson, Tobar \& Salas Guerr., sp. nov. (Figs. 2-8).

TYPE: Ecuador. Vivero ECSA, Tundayme, Gualaquiza, Morona Santiago, elevation, 822 m, 78²5'52.18”'W 3³4'3.14"S, Sept. 2016, F. Tobar \& M. Jiménez 2020 (holotype: QCNE!; isotype: QCA!).

Pleurothallis rubrifolia is superficially similar to the species of the Pleurothallis cardiostola complex, including the species Pleurothallis adelphe Luer \& Hirtz, Pleurothallis perforata Luer \& Hirtz (syn. Acronia adelphe (Luer \& Hirtz) Luer) and Pleurothallis lanigera Luer \& Hirtz and can be distinguished by several factors. P. rubrifolia can be distinguished from P. perforata by the absence of a circular cavity in the mesochile or "disc" of the lip; the abaxial surface of the leaf reddish in $P$. rubrifolia vs. green in all the $P$. 

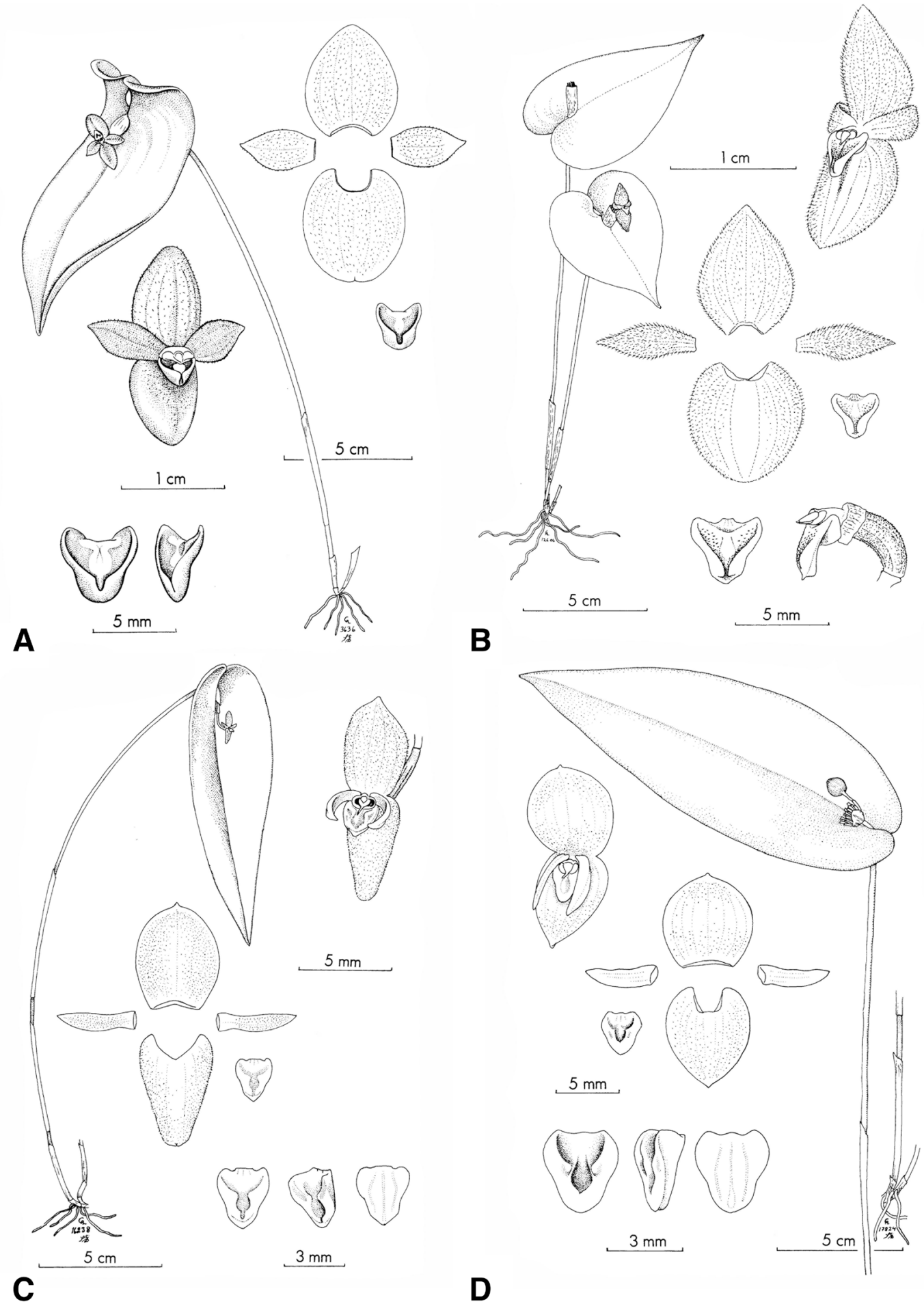

B

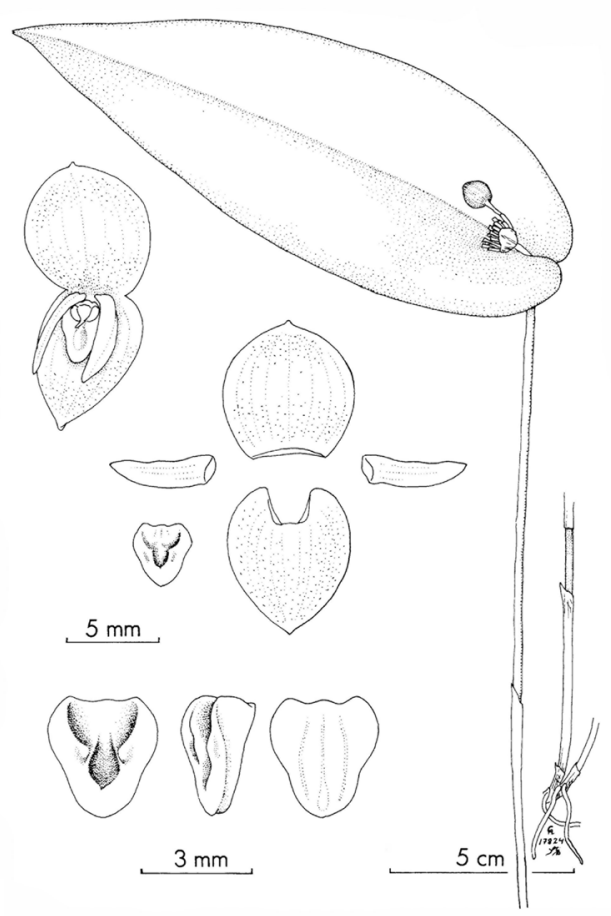

FiguRE 1. Drawings of Pleurothallis cardiostola-complex species: A. Pleurothallis cardiostola; B. Pleurothallis lanigera; C. Pleurothallis adelphe; D. Pleurothallis perforata. From Luer 2005. Courtesy of Missouri Botanic Gardens Press. 

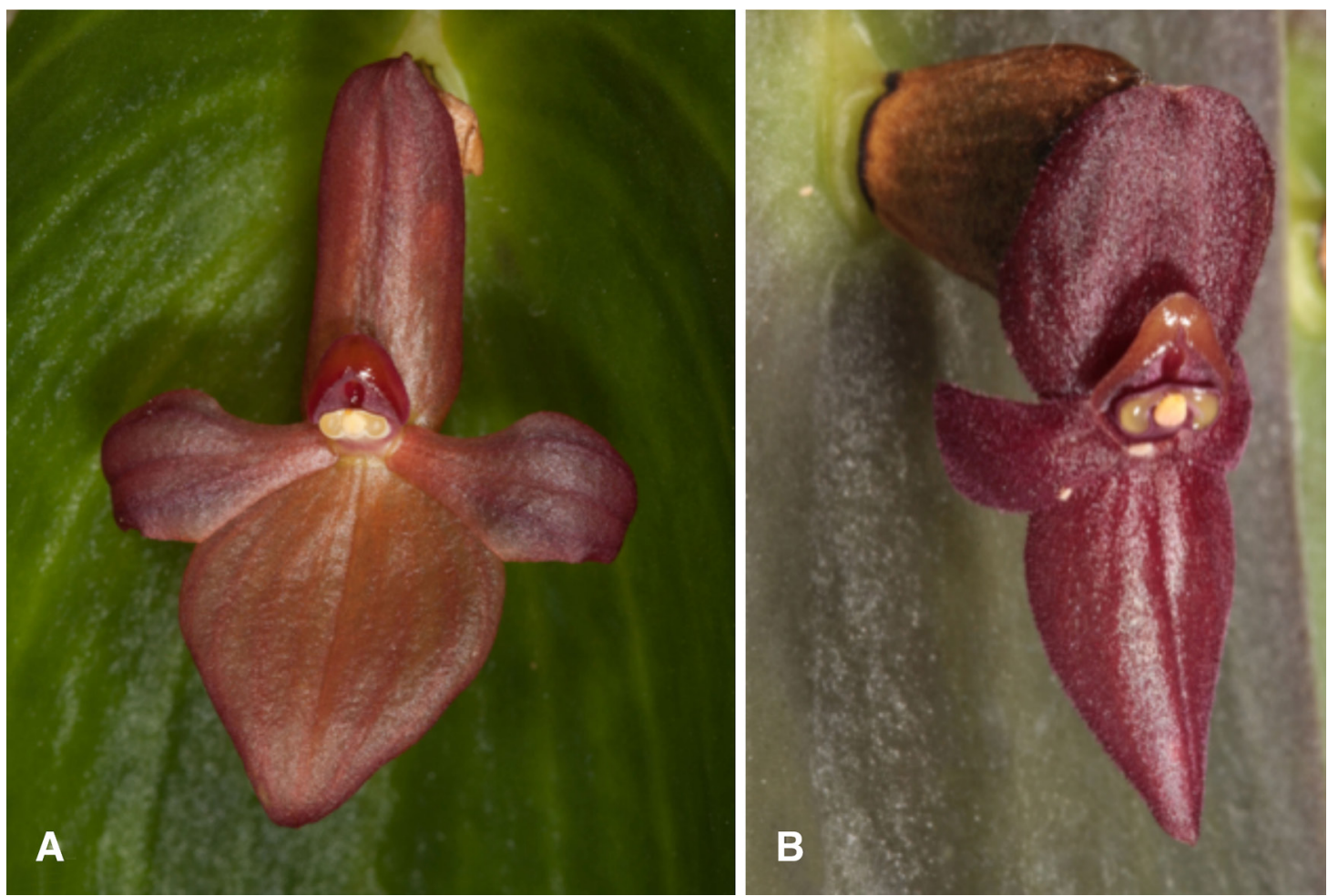

Figure 2. Comparison of Pleurothallis castanea (A) and Pleurothallis lanigera (B). Photographs by Mark Wilson.

cardiostola complex species; the mature leaf with a channel or depression towards the base in which the flower rests in P. rubrifolia vs. no depression in $P$. cardiostola complex species.

Plant medium in size, to ca. $29 \mathrm{~cm}$ tall, epiphytic, caespitose; Roots fibrous; Ramicaul terete, 7.2-19.0 $\mathrm{cm}$ long, enclosed by papyraceus basal sheath 3.0-3.8 $\mathrm{cm}$ long; Leaves sub-erect/ascendant, ovate, 8.3-11.5 $\times 3.9-5.8 \mathrm{~cm}$, acute, cordate, slightly revolute along margins, coriaceous, adaxially mottled dark green, abaxially red-brown, channeled about midrib in basal half; Inflorescence one-flowered, from reclining spathaceous bract 11-13 mm long, pedicel 6-9 mm long; Flower 1.4-1.7 × 1.4-1.5 cm, resupinate, flower resting in depression formed by channel in leaf; Dorsal sepal yellow-brown with maroon-burgundy infused along veins to darker brown with extensive maroon-burgundy at base and along veins, ovate, subacute, entire along the margins, 6.5-8.0 $\times 6.0$ $7.5 \mathrm{~mm}$, glabrous, 5-veined; Synsepal yellow-brown with maroon-burgundy infused along veins, ovate, obtuse, entire along the margins, 4.0-6.0 $\times 6.5-8.0$ mm, glabrous, 7-veined; Petals yellow-brown to darker brown, moderately to heavily infused with maroon-burgundy along vein, oblanceolate, slightly falcate, acute, entire along the margins, 2.0-2.3 $\times$ 6.0-6.4 mm, glabrous, 1-veined; Lip brown to intense burgundy-brown, triangular, obtuse, entire along the margins, $3.0-4.0 \times 3.5-4.5 \mathrm{~mm}$, glenion oval with raised callus surrounded by a depressed area, central channel; Column burgundy-brown with pale edge, stout, $1.5-2.5 \times 1.5 \mathrm{~mm}$, bilobed stigma, apical anther, anther cap yellow, viscidium pale yellow; Capsule $4.6 \mathrm{~cm}$ long.

AdDitional material STUDied: Ecuador. Natural forest near the waste dump in the northeast of project ECSA, Tundayme, Gualaquiza, Morona Santiago, elevation, 1466 m, 78²5'52.18”W 334'3.17'S, Sept. 2016, F. Tobar \& M. Jiménez 2095 (paratype: QCNE!; paratype: QCA!). Plant flowered in cultivation at Ecuagenera as Pleurothallis canidentis, without collection data M. Wilson \& J. Portilla PL0971 (paratype: HA!). Plants purchased from Ecuagenera as $P$. canidentis and flowered in cultivation at Colorado 


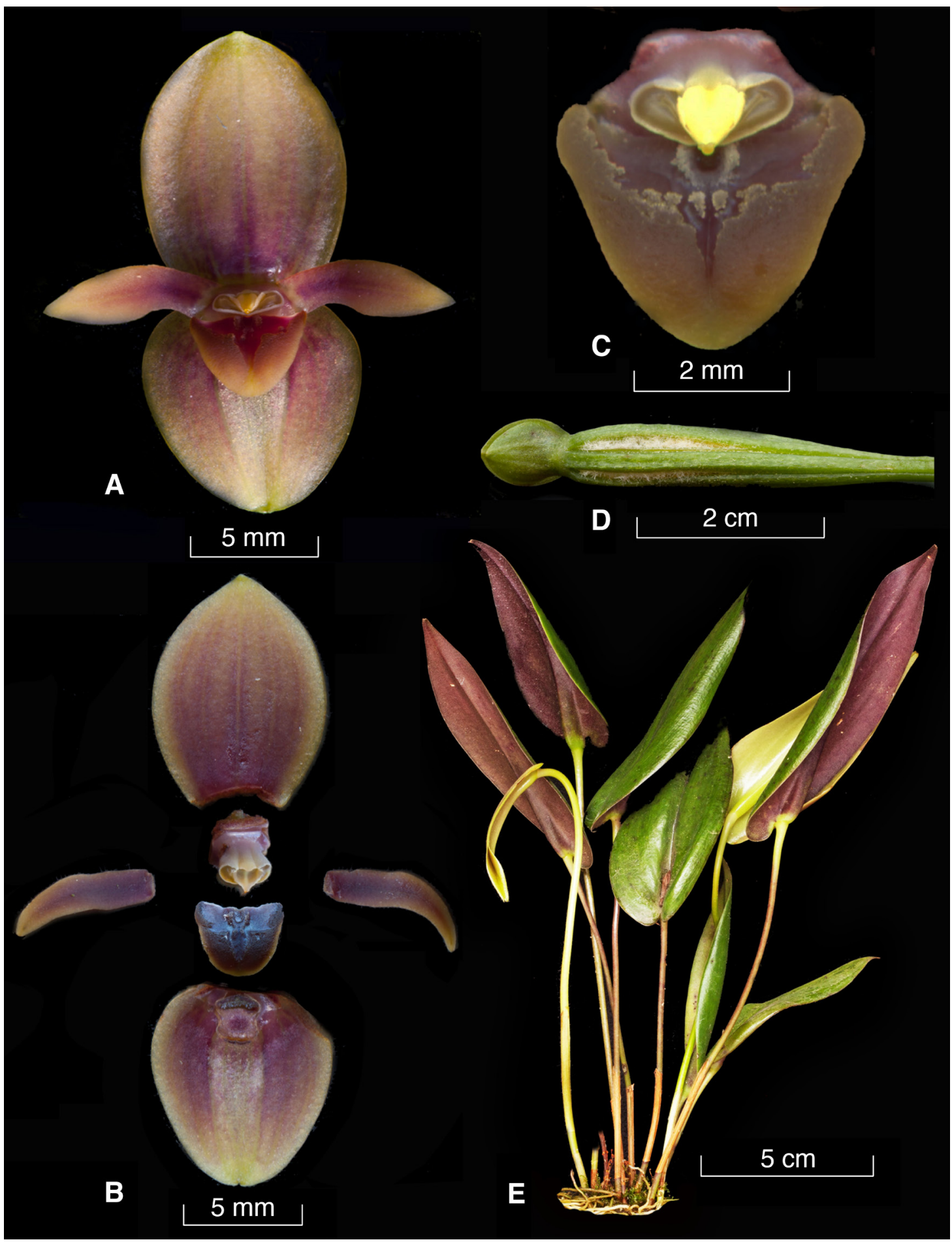

FIGURE 3. Lankester composite digital plate of Pleurothallis rubrifolia: A. Whole flower. B. Floral dissection. C. Lip and column. D. Partially dehiscent capsule. E. Whole plant illustrating red abaxial leaf surface. Prepared by Mark Wilson from the paratypes Wilson \& Portilla PL0748 and Wilson \& Portilla PL0971. 

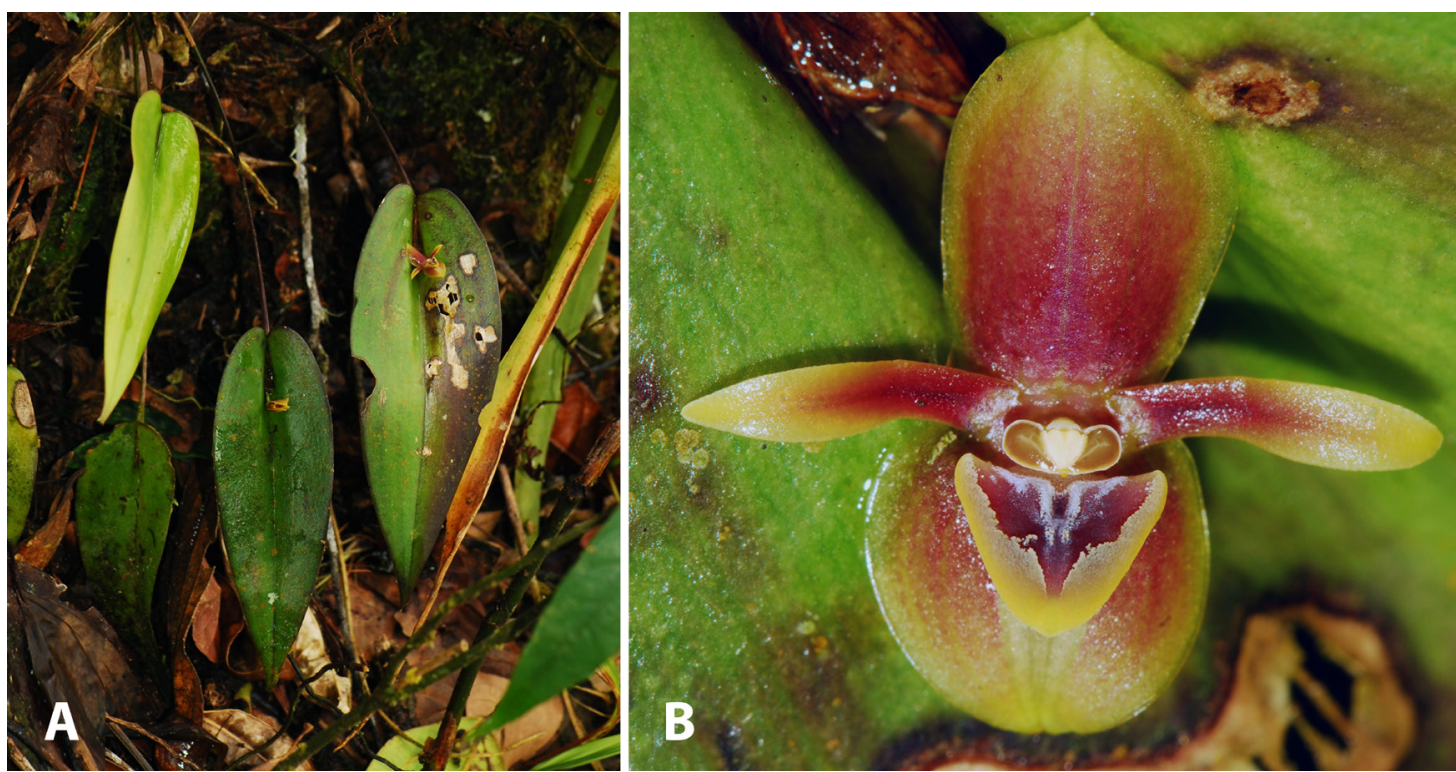

Figure 4. Pleurothallis rubrifolia in situ near Tundayme, Ecuador: A. Whole plant among roots of Arecaceae. B. Flower. Photographs by Francisco Tobar.
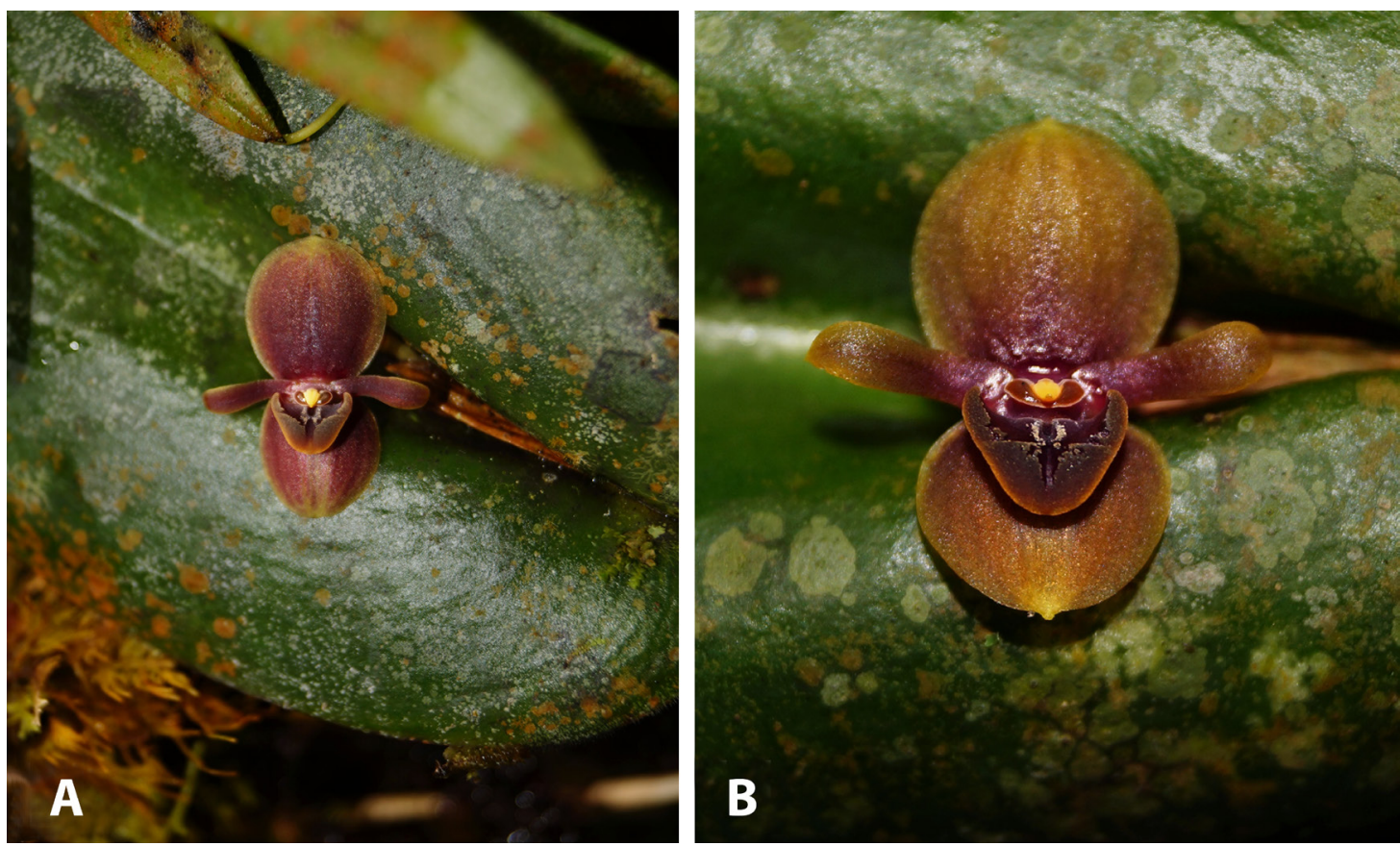

Figure 5. Pleurothallis rubrifolia in situ in Valle de Los Chilchos, Leimebamba. Peru. A. Flower on leaf. B. Flower detail. Photographs by Marco Salas.

College M. Wilson \& J. Portilla PL0177 and PL0748 (paratypes: COCO!). Peru. Albazo, Valle de Los Chilchos, Leimebamba, Cachapoyas, Salas Guerr. 0127 (paratype:USM!).
Eтymology: In reference to the unique red coloration on the abaxial leaf surface.

Distribution and habitat: Pleurothallis rubrifolia has been recorded for Tundayme, Ecuador (Fig. 13) 


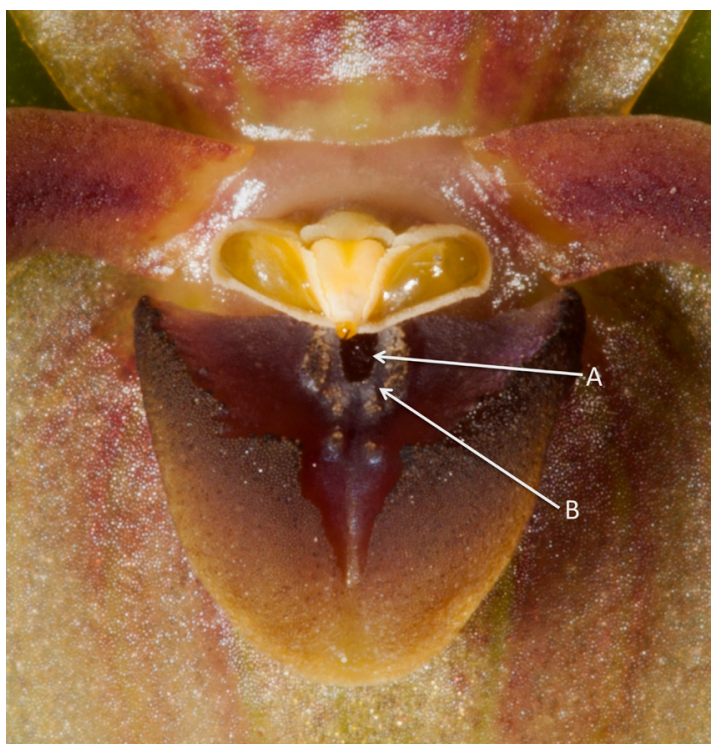

FIGURE 6. Lip and column detail for Pleurothallis rubrifolia

(A. glenion; B. callus). Photograph by Mark Wilson.

and Leimebamba, Chachapoyas, Amazonas, Peru. In Ecuador, the species grows in very humid premontane and montane forests in the Cordillera del Cóndor from 800-1700 m elevation, among the roots of Arecaceae. In Peru, it grows in very humid lower montane forest on the eastern slope of the Andes, from 1478-2015 $\mathrm{m}$ elevation, in association with plants from family Clusiaceae.
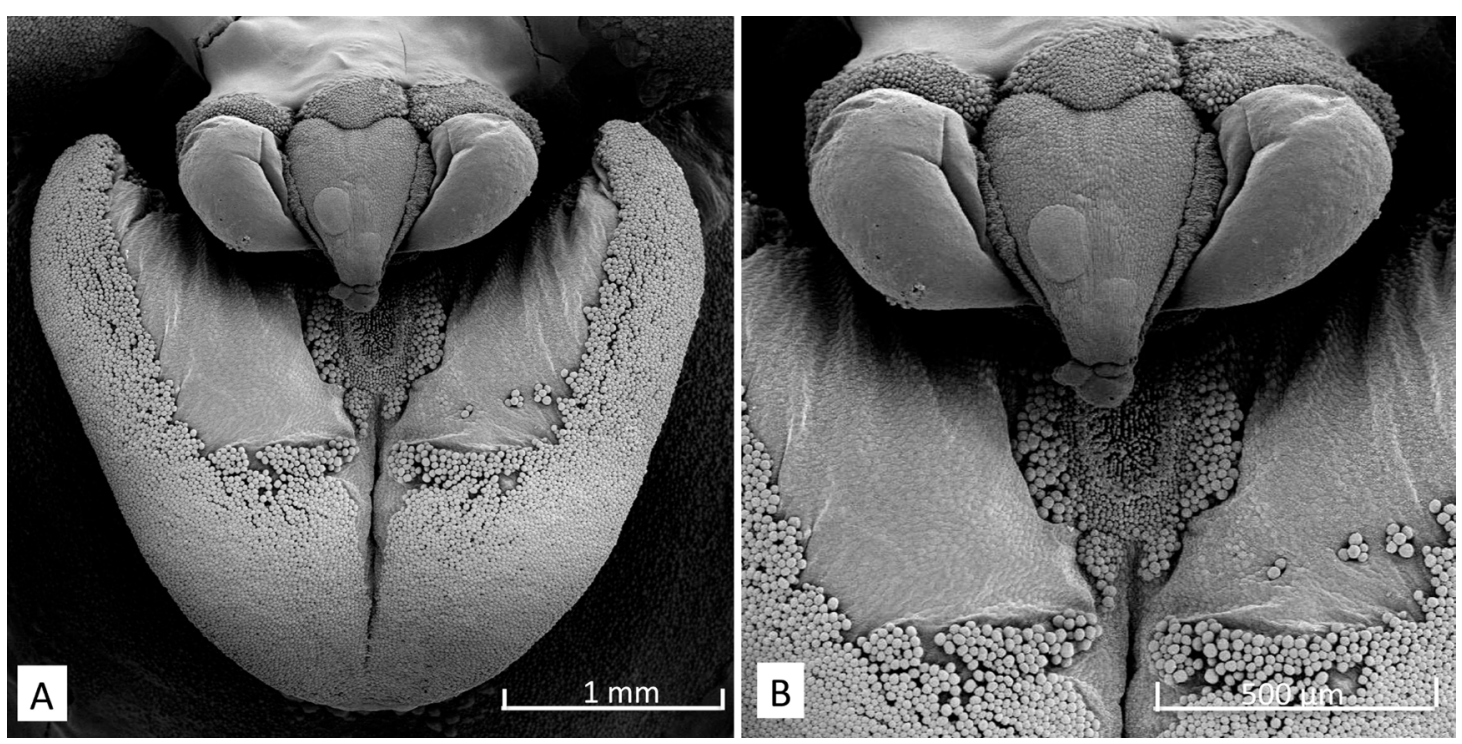

FIGURE 7. A-B. Scanning electron micrographs of lip and column of Pleurothallis rubrifolia. SEM images by Katy Dupree.

Conservation status: The type locality of Pleurothallis rubrifolia in Ecuador (Fig. 14) is within a conservation zone associated with EcuaCorriente copper-mining concession, Project Mirador, that may or may not be secure in the future. However, the abundance and breadth of distribution from southeastern Ecuador into northeastern Peru suggest that the species is not threatened in situ at this time. The species is widely distributed in collections in the U.S.A. and Europe under the name Pleurothallis canidentis, but the level of genetic diversity in these plants is probably very low, most of the plants originating from Ecuagenera, hence there is some concern regarding the ex situ conservation status of $P$. rubrifolia.

Pleurothallis rubrifolia is easily distinguished from Pleurothallis canidentis, with which it has been confused in the commercial trade, by the smaller plant size; slightly smaller leaf size; the lip brown-burgundy, triangular and planar in P. rubrifolia vs. red-brown or orange, oblong and convex in P. canidentis; the glenion raised, surrounded by callus in P. rubrifolia vs. slightly raised with no distinct surrounding callus in $P$. canidentis; and petals, dorsal sepal, synsepal yellowbrown to darker brown, moderately to heavily infused with maroon-burgundy along the veins in P. rubrifolia vs. dorsal sepal canary yellow, petals and synsepal redbrown in $P$. canidentis.

LANKESTERIANA 16(3). 2016. (C) Universidad de Costa Rica, 2016. 

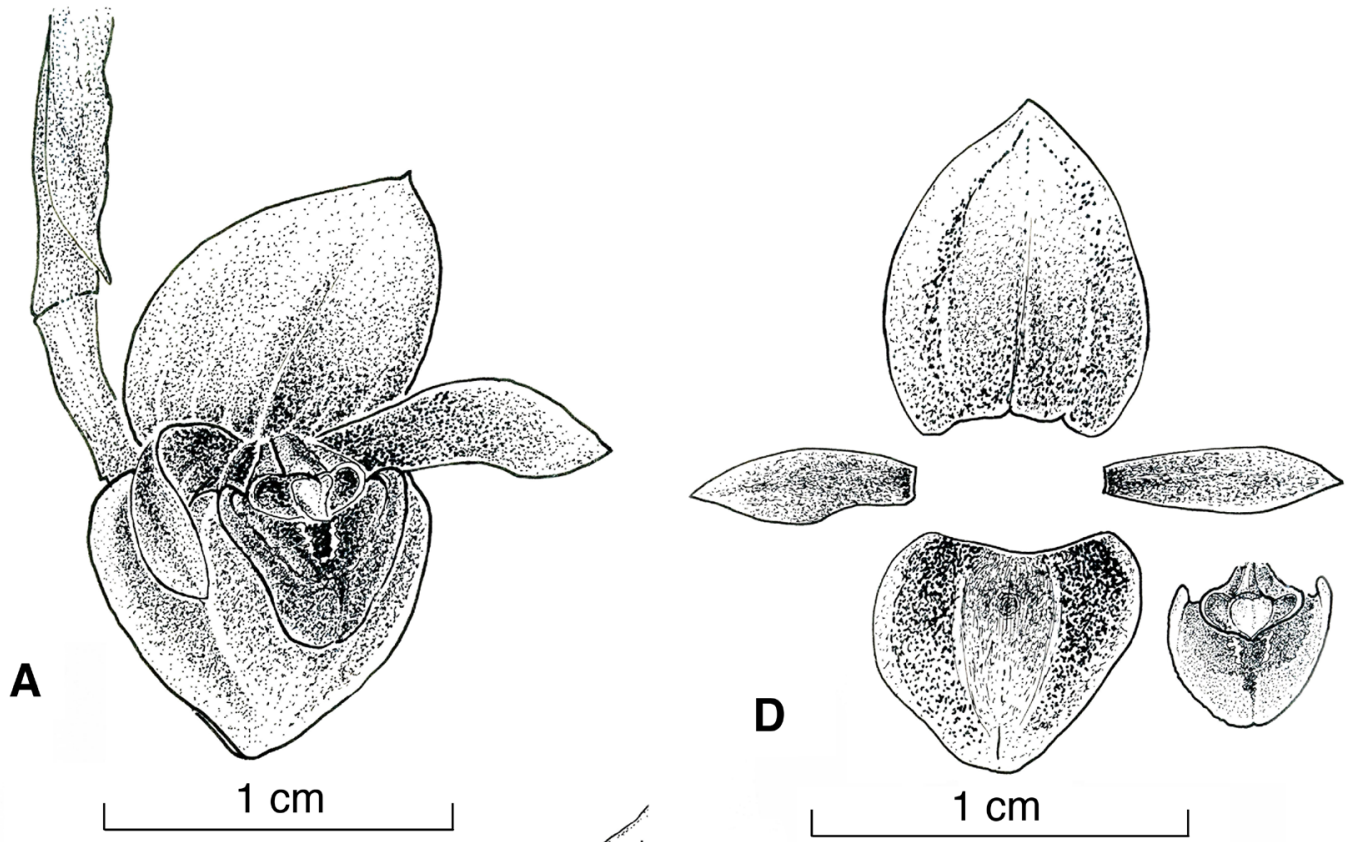

B
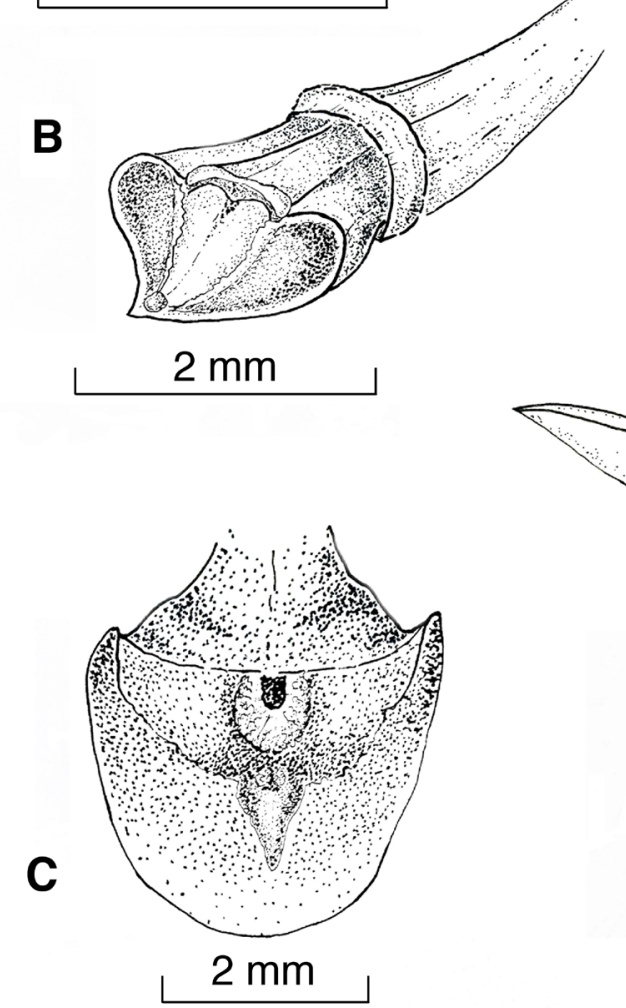
Pleurothallis castanea Mk.Wilson, G.Merino \& J.D.Werner, sp. nov. (Figs. 2A, 9-10)

TYPE: Ecuador. Flowered in cultivation at EquaflorA, without collection data, October 20, 2016, M. Wilson \& G. Merino PL0981 (holotype: HA!).

Pleurothallis castanea can be distinguished from Pleurothallis cardiostola by the glabrous sepals and petals in $P$. castanea vs. cellular-glandular to coarsely pubescent in $P$. cardiostola; the longer sepals and petals in $P$. castanea; and the leaf ovate in $P$. castanea vs. ovate to lanceolate in $P$. cardiostola. $P$. castanea is also similar to Pleurothallis lanigera Luer \& Hirtz, but differs in the sepals and petals, glabrous in $P$. castanea vs. markedly pubescent in P. lanigera.

Plant medium in size, to $\sim 16-30 \mathrm{~cm}$ tall, caespitose; Roots fibrous; Ramicaul 13-29 cm long, enclosed by papyraceus basal-sheath $4 \mathrm{~cm}$ long and mid-sheath 4 $\mathrm{cm}$ long; Leaves deflexed, spreading, cordate, apex long acuminate, entire along the margins, 6.9-10.0 $\times$ 4.3-7.0 cm, glabrous, coriaceous, the blade slightly concave; Inflorescence one-flowered from sub-erect spathe $1.5 \mathrm{~cm}$ long; Flower non-resupinate, 2.8-3.0 $\times 1.8-2.5 \mathrm{~cm}$; Dorsal sepal chestnut, broadly ovate, obtuse, slightly revolute along apical and lateral margins, $1.8 \times 1.5 \mathrm{~cm}$, glabrous, 9-veined; Synsepal chestnut, ovate, obtuse, shortly apiculate, slightly revolute along the apical and lateral margins, $1.8 \times$ $1.5 \mathrm{~cm}$, glabrous, 7-veined; Petals chestnut, obovateunguiculate, truncate-rounded, $12 \times 5 \mathrm{~mm}$, glabrous, 3-veined; Lip chestnut, ovate-triangular, $1.0 \times 1.0 \mathrm{~cm}$, with a prominent broadly triangular depression, the surface of which is verrucose, the glenion a small and bilobed cavity in front of the anther; Column creambeige suffused with pink at base, stout, $8 \times 8 \mathrm{~mm}$, with a bilobed stigma, anther apical, anther cap pale yellow, viscidium orange.

Additional material studied: Ecuador. Flowered in cultivation at Ecuagenera, without collection data, Mk.Wilson \& J.Portilla PL0958 (paratype: COCO!). Purchased from EquaflorA as Pleurothallis cardiostola Rchb.f. and flowered in cultivation by Jon Werner in U.S.A., November 2016, M. Wilson \& J. D. Werner PL0980 (paratype: COCO!).

Eтymology: In reference to the color of the sepals and petals which resemble the color of a "chestnut", nut of European and North American trees of the genus Castanea Mill.

Distribution And habitat: At this time, Pleurothallis castanea is only known from live collections in Ecuador. When describing species from greenhouse collections which have no locality information or accompanying in situ observation one must consider the possibility of a greenhouse hybrid. We believe that the characteristics of this Pleurothallis are sufficiently distinct from the other species of the Pleurothallis cardiostola complex to make the possibility that this represents a hybrid between two species of the complex highly unlikely. Further, all the plants observed at Ecuagenera and EquaflorA were very consistent in morphology, which would not be the case were they seedlings from an unintentional or intentional greenhouse hybrid. We are convinced, therefore, that $P$. castanea represents a novel species and we will continue to seek field records to confirm that this species occurs in situ and to determine a distribution for the species. The species should not, however, be added to the flora of Ecuador at this time, since it is conceivable the species was obtained from Colombia or Peru and does not occur naturally in Ecuador.

Conservation Status: In the absence of locality data we cannot assess the in situ conservation status of $P$. castanea. The ex situ conservation status is of concern, since while the species occurs in two collections in Ecuador, it is known from only one collection in the U.S. and it is quite likely that all of these plants originated from a single original plant.

Pleurothallis nangaritzae M.Jiménez, Tobar \& Mk.Wilson, sp. nov. (Figs. 11-13).

TYPE: Ecuador: Near the Nangaritza River, ZamoraChinchipe, Ecuador, $1500 \mathrm{~m}$, October $16^{\text {th }}, 2016, F$. Tobar and M. Jiménez 205 (holotype: QCNE!).

Pleurothallis nangaritzae is recognized by its large leaf size to flower size ratio; glossy, heavily veined leaf; broad petals; and papillate acute lip with shallowly bilobed glenion.

Plant small-to-medium in size, to ca. $15 \mathrm{~cm}$ tall, epiphytic, caespitose; Roots fibrous, slender; Ramicaul $10.2-12.1 \mathrm{~cm}$ long, enclosed by two sheaths, the upper 


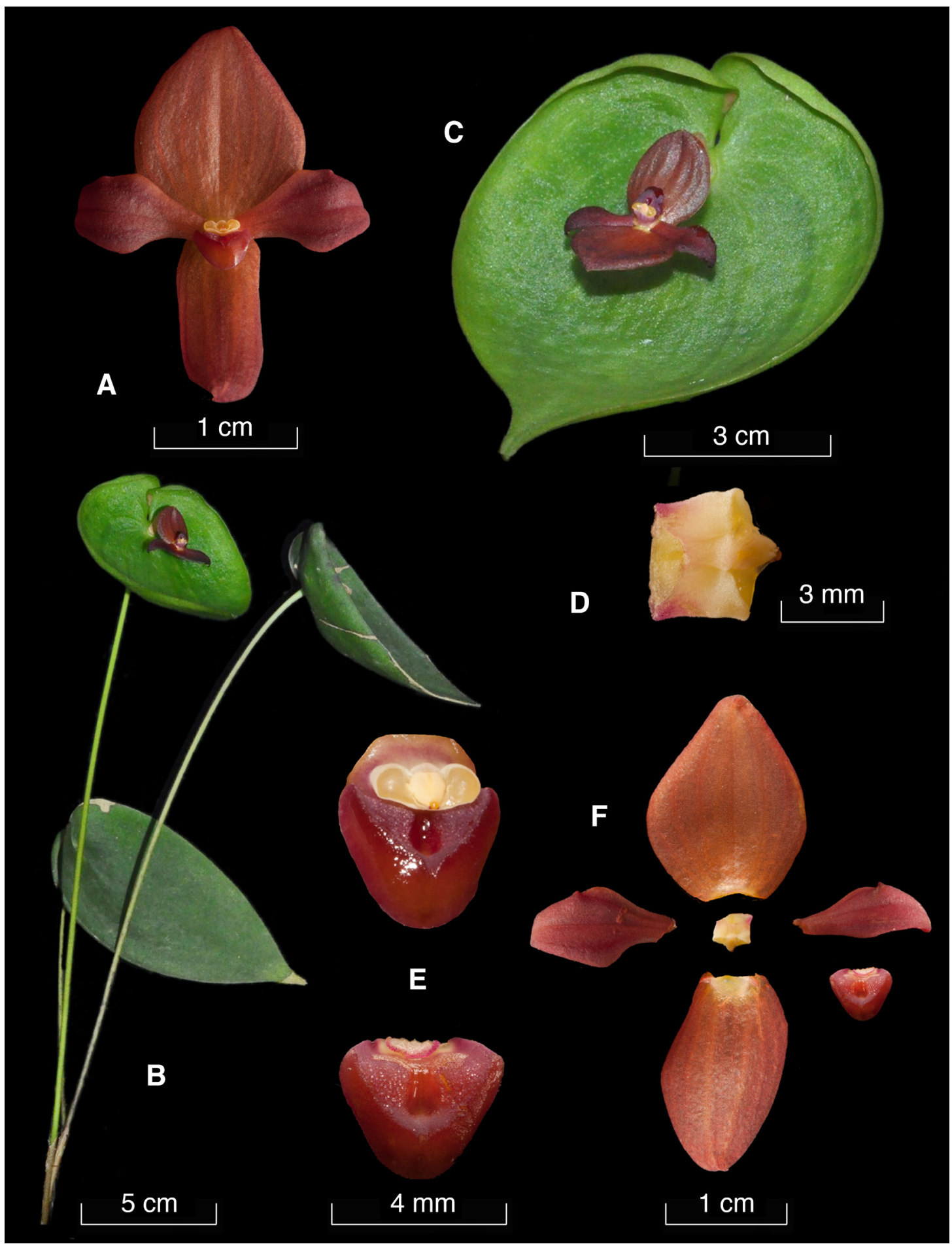

FIgURE 9. Lankester composite digital plate of Pleurothallis castanea: A. Whole flower. B. Whole plant. C. Leaf with flower. D. Lip with and without column. E. Column top view. F. Foral dissection. Prepared by Mark Wilson from the paratype Wilson \& Portilla PL0958. 


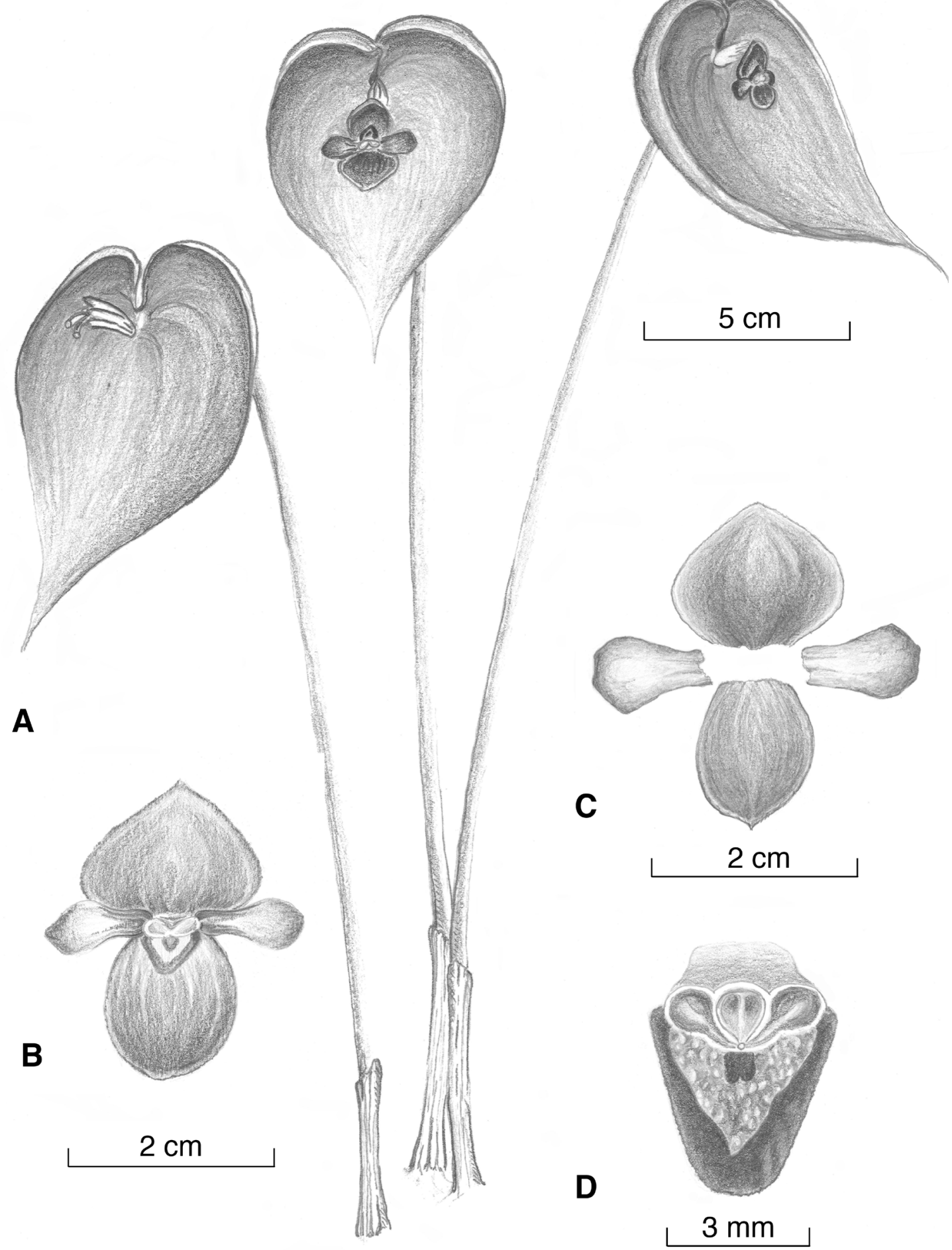

FIgURE 10. Drawing of Pleurothallis castanea: A. Whole plant. B. Whole flower. C. Floral dissection. D. Lip detail. Drawing by Jon Werner prepared from the paratype Wilson \& Werner PL0980. 


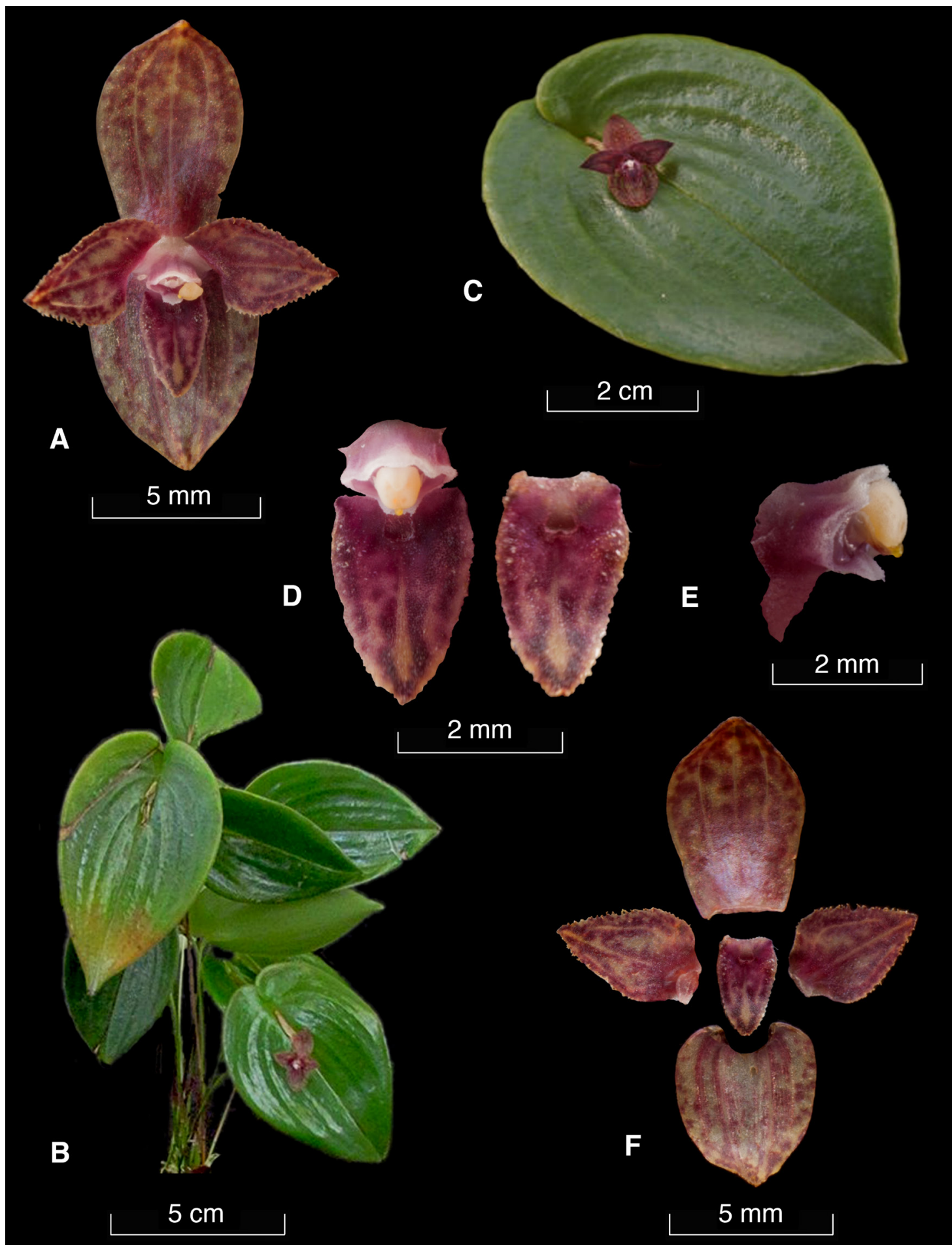

FIgURE 11. Lankester composite digital plate of Pleurothallis nangaritzae: A. Whole flower. B. Whole plant. C. Leaf with flower. D. Lip with and without column. E. Column side view. F. Floral dissection. Prepared by Mark Wilson from the paratype Wilson \& Werner PL0977. 

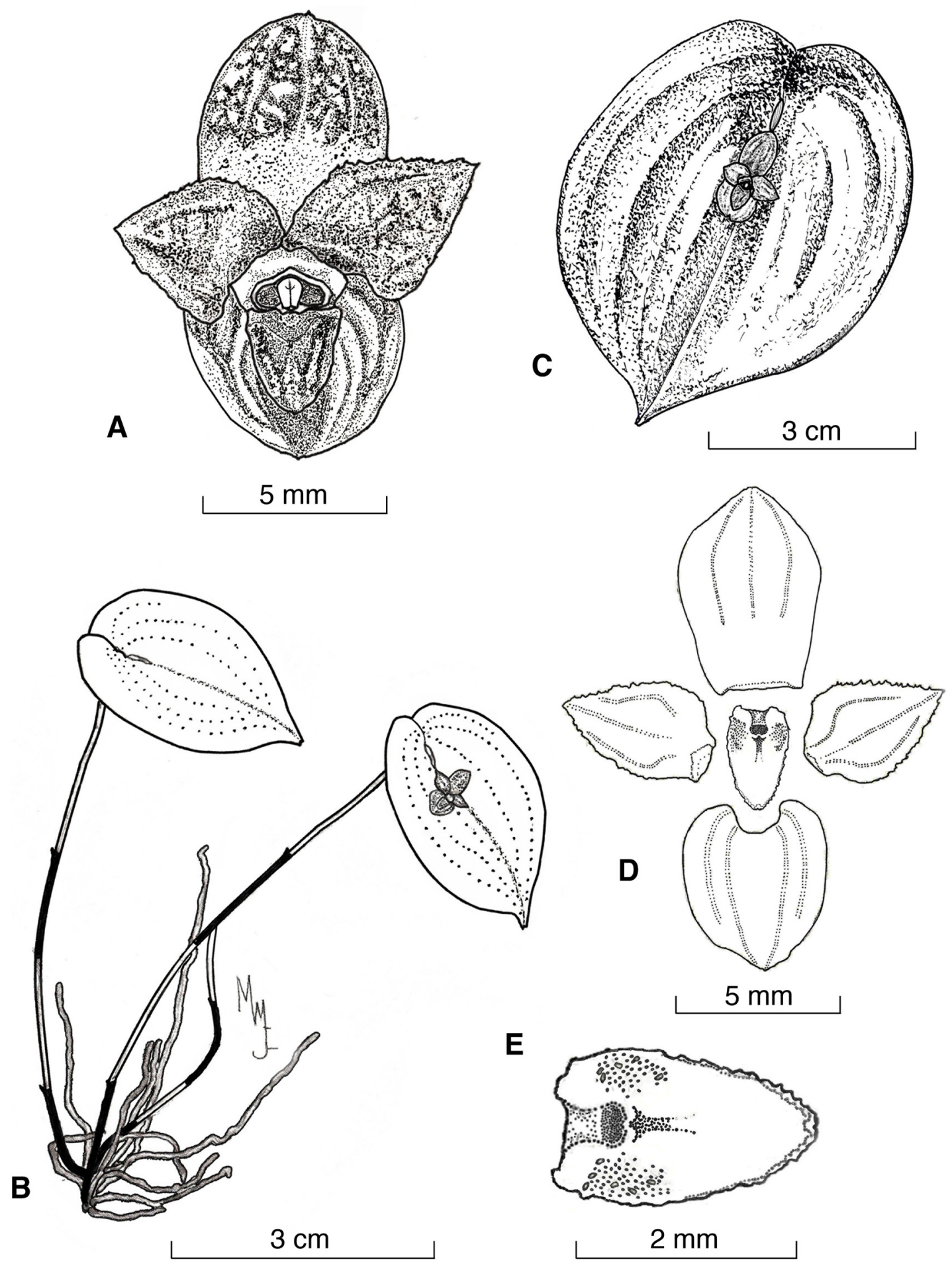

FIGURE 12. Drawing of Pleurothallis nangaritzae: A. Whole flower. B. Whole plant. C. Leaf with flower. D. Floral dissection.

E. Lip. Drawings by Marco Jiménez and Luis Baquero prepared from holotype Tobar and Jiménez 2050. 
sheath $0.85-1.3 \mathrm{~cm}$ long and the lower $2-4 \mathrm{~mm}$ long; Leaves deflexed, almost totally plain, ovate, acute, apiculate, shallowly cordate, $3.5-6.8 \times 1.4-3.85 \mathrm{~cm}$, glossy, coriaceous and heavily veined; Inflorescence one-flowered from reclining spathe $5-8 \mathrm{~mm}$ long, peduncle 2-3 $\mathrm{mm}$ long, pedicel $4-5 \mathrm{~mm}$ long, floral bract 3-4 mm long; Flower 10.7-13.3 × 7.8-10.0 mm, resupinate; Dorsal sepal beige with burgundy mottling, somewhat concave in apical half, elliptical-obovate to oblong-obovate, obtuse, entire along the margins, 5.0 $\times 3.0 \mathrm{~mm}$, glabrous, 3-veined; Synsepal beige partially mottled with burgundy, slightly concave, ovate, obtuse, entire along the margins, $4.0 \times 3.0 \mathrm{~mm}$, glabrous, 5-veined; Petals beige mottled with burgundy, base entirely burgundy, ovate and shortly unguiculate, acute, marginally dentate, $4.5 \times 3.2 \mathrm{~mm}$, glabrous, 3-veined; Lip beige heavily mottled with burgundy, narrowly obovate, acute, marginally papillate-dentate, $3 \times 2 \mathrm{~mm}$, the glenion a small area in front of the anther, bilobed, surrounded by narrow callus; Column pink to pale burgundy with white along the edge of the clinandrium, stout, somewhat compressed dorsiventrally, $1.0 \times 1.5 \mathrm{~mm}$, with a bilobed stigma, anther apical, anther cap pale yellow, viscidium drop-like, orange.

Additional material studied: Ecuador. Purchased from Mundiflora and flowered in cultivation by Jon Werner in U.S.A., M. Wilson \& J. D. Werner PL0977 (paratype: $\mathrm{COCO}$ !)

Etymology: Named for the type locality near the Nangaritza River in Zamora Chinchipe Province, Ecuador.

Distribution AND haBitat: So far, Pleurothallis nangaritzae is known in the wild from only the type locality near the Nangaritza River, Province of Zamora Chinchipe, Ecuador (Fig. 13): it has not, to date, been reported outside this Province and may be endemic to that region. $P$. nangaritzae grows as an epiphyte adpressed to tree trunks in a lower montane forest at an elevation of $\sim 1500 \mathrm{~m}$ and occurs sympatrically with orchids such as Masdevallia strobelii H.R.Sweet \& Garay, Maxillaria pachyacron Schltr., Oncidium tipuloides Rchb.f. and Pleurothallis cordata Lindl.

Conservation STATUS: The type locality of Pleurothallis nangaritzae occurs in an area in which a road has been

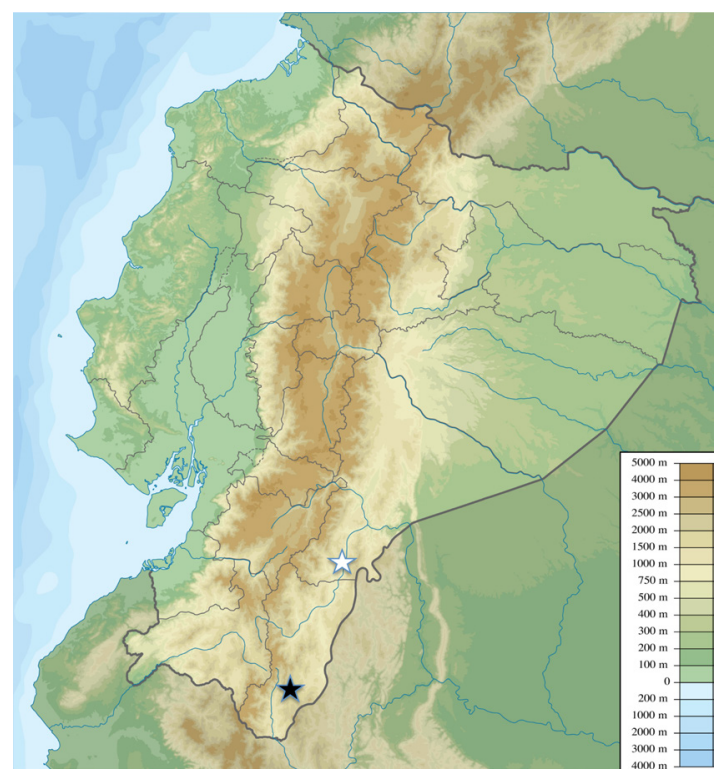

FIgURE 13. Collection locations of Pleurothallis nangaritzae (black star) and Pleurothallis rubrifolia (white star) in southeastern Ecuador (map from Wikimedia commons.)

opened and at this time cannot be considered secure. Whether the species occurs within the Bosque Protector Alto Nangaritza is unknown. The ex situ conservation status is also of concern, since while the species occurs in two collections in Ecuador, it is known from only one collection in the U.S. and likely all of these plants originated from a single original plant.

\section{Discussion}

Pleurothallis subsection MacrophyllaeFasciculatae is the most speciose group within genus Pleurothallis as circumscribed by Pridgeon et al. (2005), with between 223 and 297 species, depending on synonymy. The first author estimates that, even conservatively, only $\sim 60-70 \%$ of the species in the subsection have been described. Hence, a significant amount of work will be required in this group in order to describe the extant biodiversity before it is lost to deforestation and climate change. Efforts should be directed to areas of high biodiversity and endemism which have received little attention by orchidologists to date: the northwest of Ecuador (Endara, Williams \& Léon-Yánez 2009) and the southwest of Colombia, particularly the Department of Nariño (Orejuela Gärtner 2011), part of the Chocó bioregion; and 
the southeast of Ecuador (Endara et al. 2009) and adjoining areas of Amazonas, Peru. Unfortunately, the description of new species is somewhat hampered by the large number of superficially similar species in this group.

We believe that the micro-morphology of the labellum and in particular the glenion, the structures with which the pollinator interacts directly, may be the most useful for distinguishing otherwise morphologically similar species in Pleurothallis subsection Macrophyllae-Fasciculatae. In this group, nearly all of which possess such a structure, the glenion is a small area of the hypochile, of distinct tissue structure, often depressed, but occasionally elevated on a callus, surrounded by tissue of completely different texture. While often mentioned in descriptions of species in the Macrophyllae-Fasciculatae, to our knowledge, it has not been examined in detail using SEM in this or any other group within Pleurothallis sensu Pridgeon et al. (2005). We hypothesize that it acts not just to attract the pollinator but that it serves to position the pollinator in the optimal position for pollinarium acquisition or deposition.

All three of the species described herein possess a glenion, but we were only able to obtain detailed images of the glenion of Pleurothallis rubrifolia. The glenion of $P$. rubrifolia was very distinctive, being somewhat elevated on a callus; apparently consisting of three cell types; and being surrounded by a smooth, somewhat depressed area of the hypochile/mesochile (Fig. 6-7). The glenion of Pleurothallis nangaritzae is bilobed, (Fig. 11b), a rare character in Pleurothallis subsection Macrophyllae-Fasciculatae, with few papillae along the outer edges. The papillae cover a large portion of the lip and surround a triangular area of smooth tissue, with the glenion at the base (Fig. 14). The P. rubrifolia glenion was quite different from that in Stelis, in which Ignowski (2015) observed the glenion to consist of a less well-defined area of tall, slender, loosely packed, papillate cells. Based upon the observations of Ignowski (2015) in Stelis and the preliminary observations here, the utility of the glenion in taxonomic discrimination of morphologically similar species and its specific role in the reproductive ecology of Pleurothallis subsection MacrophyllaeFasciculatae deserves further study.

Although Pleurothallis rubrifolia, P. castanea and

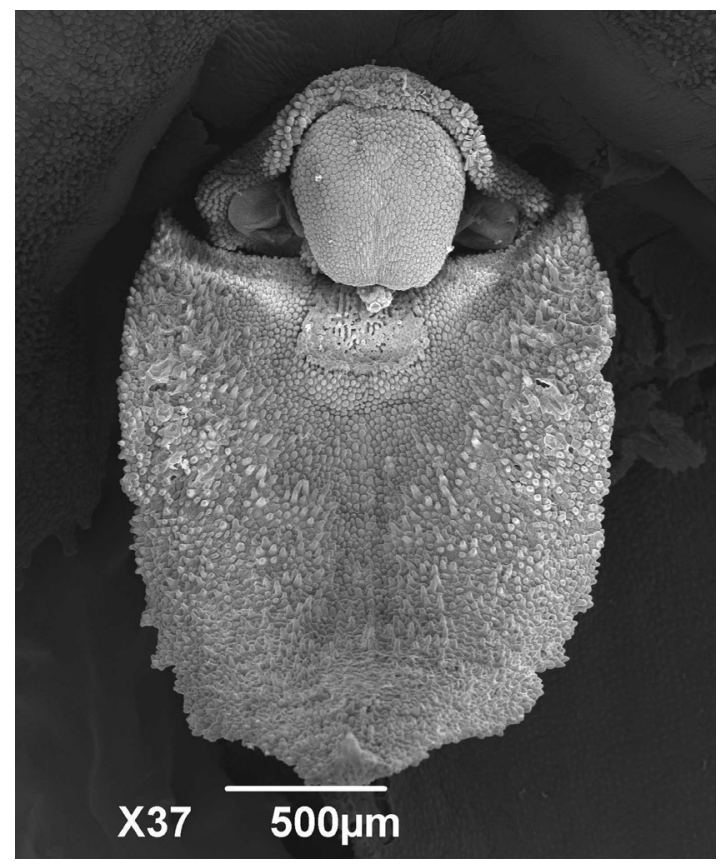

FIGURE 14. Scanning electron micrographs of lip and column of Pleurothallis nangaritzae. SEM image by Katy Dupree.

P. nangaritzae are present in hobbyist, commercial and botanic collections in North and South America, ex situ conservation is a very poor substitute for in situ conservation in tropical montane forests (Orejuela Gärtner 2011). These forests, however, are extremely vulnerable due to deforestation and climate change (Orejuela Gärtner 2011) and while modest orchid conservation efforts are underway through organizations such as the Orchid Conservation Alliance (OCA), EcoMinga in Ecuador and Salvamontes in Colombia, significantly more effort and funding will be required to conserve even a small fraction of the diversity of these species in the coming decades.

ACKNOWLEDGEMENTS. The authors are grateful to Colorado College for research funding for Wilson and Dupree and provision of greenhouse and herbarium facilities; to Dr. Ron Hathaway for assistance with SEM; to Ecuagenera, EquaflorA and Mundiflora for access to plant collections; to members of the Portilla family for their warm hospitality; to EcuaCorriente for the facilities provided under Project Mirador and for the use of their investigation permit allowing collection of the species described; to Ecotono for aid with the field logistics and the use of the transportation 
permit for the species described; to Adam Karremans and Diego Bogarín for instruction in preparation of LCDPs; to the anonymous reviewers for extremely valuable suggestions to improve the species descriptions; and the Editors of Lankesteriana for other suggestions to improve the manuscript.

\section{Literature Cited}

Bennett, D. E. \& Christenson, E. A. (1993). Icones Orchidacearum Peruvianum. St. Louis: Missouri Botanical Gardens Press.

Cardoso-Gustafson, P. (2014). Desenvolvimento floral em espécies de Pleurothallidinae (Orchidaceae) com ênfase nas estruturas secretoras. Ph.D. Thesis, Instituto de Botânica da Secretaria do Meio Ambiente, São Paulo, Brazil.

Dodson, C. H. (2003). Native Ecuadorian orchids, vol. 4: Oncidium to Restrepiopsis. Sarasota, FL, U.S.A.: Dodson Trust.

Dodson, C. H. \& Dodson, P. M. (1980). Orchids of Ecuador, Series 1, Fascicles 1-4, Icones Plantarum Tropicarum. Sarasota, FL, U.S.A.: Marie Selby Botanic Gardens.

Dodson, C. H. \& Dodson, P. M. (1982). Orchids of Ecuador, Series 1, Fascicles 5, Icones Plantarum Tropicarum. Sarasota, FL, U.S.A.: Marie Selby Botanic Gardens.

Dodson, C. H. \& Dodson, P. M. (1991). Orchids of Ecuador, Series 2, Fascicles 5-6, Icones Plantarum Tropicarum. Sarasota, FL, U.S.A.: Marie Selby Botanic Gardens.

Doucette, A., Wilson, M., Portilla, J., Kay, A., Moreno, J. S., \& Cameron, K. M. (2016). Two new species of Pleurothallis and a new name for Acronia rinkei. Orquideología 23(2): 123-139.

Duque, Ó. (2008). Orchidaceae Stelis Swartz compendium. Medellin, Colombia: Editorial Universidad de Antioquia.

Endara, L., Williams, N. H. \& Léon-Yánez, S. (2009). Patrones de endemismo de orquídeas ecuatorianas: perspectivas y prioridades para la conservación. In: A. M. Pridgeon \& J. P. Suárez, (Eds.) Proceedings of the Second Scientific Conference on Andean Orchids (6370). Loja, Ecuador: UTPL.

Escobar, R. (1994). Native Colombian orchids, vol. 3, Maxillaria-Ponthieva. Medellín, Colombia: Compañia Litográfica Nacional S.A.

Escobar, R. (2006). Native Colombian orchids, vol. 6, supplement: Leucochyle-Zootrophion. Medellín, Colombia: Compañia Litográfica Nacional S.A.

Ignowski, H. (2015). Stelis Swartz (Orchidaceae) no estado do Paraná e estudos micro-morfológicos florais do gênero. Ph.D. Thesis, Universidade Federal do Paraná, Brazil.
Ignowski, H., Toscano de Brito, A. L. V., Bona, C. \& de Camargo Smidt, E. (2015). Nomenclatural notes on Stelis ciliaris (Pleurothallidinae, Orchidaceae). Phytotaxa 218(1): 030-038. http://dx.doi.org/10.11646/ phytotaxa.218.1.2

Kolanowska, M., Pérez-Escobar, O. A., Sanchez, E. P. \& Szlachetko, D. (2011). An illustrated field guide to the orchids of the Yotoco Forest Reserve (Colombia).

Lindley, J. (1859). Folia Orchidaceae Pleurothallis 9-12.

Luer, C.A. (1974). Icones Pleurothallidinarum: Pleurothallis of Ecuador (Orchidaceae). Selbyana 1(1), 56-100.

Luer, C. A. (1975a). Icones Pleurothallidinarum (Orchidaceae): Pleurothallis of Ecuador II. Selbyana 1(2), 172-195.

Luer, C. A. (1975b). Icones Pleurothallidinarum (Orchidaceae): Pleurothallis of Ecuador III. Selbyana 1(3), 220-303.

Luer, C. A. (1976). Icones Pleurothallidinarum: Miscellaneous species of Pleurothallis. Selbyana 3(12), 38-201.

Luer, C. A. (1977). Icones Pleurothallidinarum (Orchidaceae): Miscellaneous species in the Pleurothallidinae. Selbyana 3(3-4), 203-407.

Luer, C.A. (1986). Icones Pleurothallidinarum III: Systematics of Pleurothallis. Monographs in Systematic Botany from Missouri Botanical Garden 20, 1-109.

Luer, C. A. (1988). A revision of some sections of subgenus Pleurothallis. Lindleyana 3(3), 133-149.

Luer, C. A. (2005). Icones Pleurothallidinarum XXVII: Dryadella and Acronia section MacrophyllaeFasciculatae. Monographs in Systematic Botany from Missouri Botanical Garden 103, 1-311.

Luer, C. A. (2009). Miscellaneous new species in the Pleurothallidinae (Orchidaceae). Selbyana 30(1), 1-71.

Luer, C. A. (2011). Miscellaneous new species in the Pleurothallidinae (Orchidaceae) excluding species from Brazil. Harvard Papers in Botany 16(2), 311-360.

Luer, C. A. \& Thoerle, L. (2013). Miscellaneous new species in the Pleurothallidinae (Orchidaceae). Harvard Papers in Botany 18(2), 173-196.

Orejuela Gärtner, J. E. (2011). Orchids in the Mist: Orchids of the cloud forests of southwestern Colombia. Cali, Colombia: El Color de Colombia Ediciones Artísiticas.

Pridgeon, A. M., Cribb, P.J., Chase, M. W. \& Rasmussen, F. N. (2005). Genera Orchidacearum. Vol. 4. Epidendroideae (Part one), (385-390). Oxford, U.K.: Oxford University Press

Pridgeon, A. M. \& Chase, M. W. (2001). A phylogenetic reclassification of Pleurothallidinae (Orchidaceae). Lindleyana 16, 235-271.

Pridgeon, A. M., Solano, R. \& Chase, M. W. (2001). Phylogenetic relationships in Pleurothallidinae (Orchidaceae): Combined evidence from nuclear and 
plastid DNA sequences. American Journal of Botany 88, 2286-2308.

Schweinfurth, C. (1959). Orchids of Peru. Fieldiana Botany 30(2), 261-531.

Schweinfurth, C. (1970). First Supplement to the Orchids of Peru. Fieldiana - Botany 33, 1-85.

Szlachetko, D. L. \& Kulak, M. (2006a). Nouvelles combinaisons dans le genre Zosterophyllanthos Szlachetko \& Margónska (Orchidaceae, Pleurothallidinae). Richardiana (3), 131-135.

Szlachetko, D. L. \& Kulak, M. (2006b). Nouvelles combinaisons dans le genre Zosterophyllanthos Szlachetko \& Margónska (Orchidaceae, Pleurothallidinae). Richardiana (4), 183-196.

Szlachetko, D. L. \& Margonska, B. H. (2001). Genera et species orchidalium. Polish Botanical Journal 46(2), 113-121.

Szlachetko, D. L., Veyret, Y., Mytnik-Ejsmont, J., Sawicka, M., Rutkowski, P. and Baranow, P. (2012). Orchids of French Guiana. Liechtenstein: A. R. G. Gartner, Ruggell.

Wilson, M., Belle, C., Dang, A., Hannan, P., Kenyon, C., Low, H., Stayton, T. \& Woolley, M. A. (2011). A phylogenetic analysis of the genus Pleurothallis, with emphasis on Pleurothallis subsection MacrophyllaeFasciculatae, using nuclear ITS and chloroplast DNA sequencing. Lankesteriana 11(3), 369. http://dx.doi. org/10.15517/lank.v11i3.18304

Wilson, M., Belle, C., Dang, A., Hannan, P., Kellogg, L., Kenyon, C., Low, H., Mochizuki, A., Nguyen, A., Sheade, N., Shan, L., Shum, A., Stayton, T., Volz, C., Vosburgh, B., Wellman, H. \& Woolley, M. A. (2013). Preliminary phylogenetic analysis of Pleurothallis sensu lato based upon nuclear and plastid sequences. Lankesteriana 13(1-2), 139. http://dx.doi.org/10.15517/ lank.v0i0.11568

Zelenko, H. \& Bermúdez, P. (2009). Orchids: Species of Peru. Quito, Ecuador: Imprenta Mariscal. 